\title{
From Provision of Information, Through Activation, to Changing the Social World. The Amazonki Associations as a Source of Comprehensive Support for Women with Breast Cancer
}

\begin{abstract}
This work presents the phenomenon of mutual help and social support in a group of patients with breast cancer, against the background of transformations of the whole Amazonki (Amazons) movement. Social organizations embracing women after breast cancer treatment have been operating in Poland for over 30 years. In that time, they have proven their usefulness and importance. Since the beginning of their existence, the Amazons clubs were oriented to providing support, widely understood, to women patients in oncological wards and club members; they have been successful in that area so far. What is important is the fact that individual clubs of women after cancer treatment are not separate social units, but form a federation which, since the early 1990s, has been directing the process of rationalizing their operations. This work describes that process in general and presents the stage at which the Amazons movement is at present. What is interesting, the stagnation which has overcome the whole movement seems to have little or no effect at all on the functioning of separate associations, which pursue their statutory goal to support sick women in recovery and improve their quality of life.
\end{abstract}

Keywords: social support, support group, breast cancer, women's social movement, Associations of "Amazons", Poland.

\footnotetext{
* Institute of Pedagogy, University of Wroclaw.
} 


\title{
Od dostarczania informacji po aktywizację do zmiany społecznego świata. Stowarzyszenia Amazonek jako źródło kompleksowego wsparcia dla kobiet $\mathrm{z}$ rakiem piersi
}

\begin{abstract}
Abstrakt
Przedmiotem tego tekstu jest zjawisko wzajemnej pomocy i wsparcia społecznego $\mathrm{w}$ grupie pacjentek z rakiem piersi, ukazane na tle przemian zachodzących w całym ruchu Amazonek. Organizacje społeczne, skupiające kobiety po leczeniu raka piersi, funkcjonują w Polsce od ponad 30 lat. Przez ten okres dowiodły swojej przydatności i ważności. Od początku swojego istnienia kluby Amazonek zorientowane były na udzielanie szeroko rozumianego wsparcia pacjentkom na oddziałach onkologicznych oraz swoim członkiniom - do dzisiaj dobrze się z tego zadania wywiązują. Istotne jest, że poszczególne kluby kobiet po leczeniu raka nie stanowią osobnych bytów społecznych, ale współtworzą federację, która od początku lat 90. XX w. kieruje procesem racjonalizacji ich działań. W tekście ogólnie ukazano, jak ten proces przebiegał i w jakiej fazie znajduje się obecnie ruch Amazonek. Co ciekawe, stagnacja, która ogarnęła cały ruch, wydaje się nie oddziaływać lub oddziałuje jedynie w niewielkim stopniu na funkcjonowanie poszczególnych stowarzyszeń, realizujących swój statutowy cel, to jest wspieranie chorujących kobiet w powracaniu do zdrowia i w podnoszeniu jakości życia.
\end{abstract}

Słowa kluczowe: wsparcie społeczne, grupa wsparcia, rak piersi, ruch społeczny kobiet, Stowarzyszenie Amazonki, Polska.

\section{Introduction}

This work analyses the "efficiency" of the Polish social movement formed by associated patients with breast cancer, involving the provision of support, widely understood, to patients at various stages of recovery. The Amazons have existed and operated in Poland for over three decades; the movement was formed towards the end of the socialist system, survived the political transformation, and found a place for itself in the capitalist democracy. Its social activities have brought important cultural and political changes and, what follows, they have had an important effect on the improvement of individual patients' functioning. However, at present one should consider whether Amazons clubs still satisfy the need of support of their members and other patients. Many things have changed for the better in Poland, and the support of the clubs may seem unnecessary now. For example, screening programmes for breast cancer in women within specific age brackets are widely accessible now, so the Amazons do not have to import old mammographs from the West, using private means; rehabilitation services have been privatized and each person with sufficient personal funds may use them (therefore, they do not have to be an Amazons member unless they want to take part in quasi-sport classes "free of charge" for a small membership fee); the 
purchase of breast prostheses and wigs is not difficult anymore; and specialist psycho(onco)logical support is offered both for a fee and free of charge (not only by the Amazons associations) etc. Moreover, the clubs themselves have undergone a certain transformation, although they emphasize very much their attachment to tradition and the mission chosen at their beginning.

In this superficial, out of necessity, image of the "Amazons phenomenon", I point to areas where social support is still provided (i.e. the main goal of the associations of women with breast cancer is still accomplished). I also wonder how much the clubs' offer reflects the needs of modern, emancipated, and, increasingly, younger patients. The Amazons clubs (with several exceptions) show greater and greater organizational apathy; however, their presence in Polish society (whose spirit of citizenship is still not awakened) is exceptionally important and necessary. Moreover, the number of women of 40 or below with breast cancer is growing and they have difficulties in finding the assistance they need and space for taking action in the existing clubs (which are oriented at women over 60). A reflection on issues related with a break in the inter-generational exchange seems very urgent otherwise the clubs will "expire" and younger patients will have difficulties in moving efficiently in a maze of commercial offers and opposing oppressive media images of breast cancer. This work, as intended by the author, is also an opinion in the discussion, which is still very weak, on how to change the existing situation. Therefore, the conclusion includes hints concerning the direction of possible actions to be taken by the Polish Amazons associations.

\section{"Activist turn" in Poland?}

The times when patients with cancer avoided publicizing information on their health condition for fear of being stigmatized and socially excluded are, it seems, gone forever. At present, cancer patients are expected to speak about their condition openly, but, to tell the truth, about the psychological and social aspect of their well-being rather than the ailments of their body. For some time, it has been generally believed that avoiding sharing one's experiences from a period of disease is a factor preventing recovery or even favouring a recurrence of cancer (cf. e.g. Easley 2019; Munro, Scott, King, Grunfeld 2015). There are many public spaces available to patients who have decided to respond to that new cultural call, from Internet websites dedicated to medical issues, discussion forums, blogs, Facebook profiles, broadcasts and articles in the mass media, to self-help and support groups with the main purpose of providing patients with professional or non-professional assistance.

The words of Susan Sontag (1999), who said that a diagnosis of cancer is like receiving a ticket to exile from, as expressed by Christopher Hitchens (2013), the world of the living to the world of the tumour, are slowly becoming outdated. 
A completely new phenomenon may be observed, i.e. becoming elevated to a higher and more exposed social position. Oncological patients, those who publically share their histories, usually obtain the status of onco-celebrities (a name created by Jan Kaczkowski, cf. Kaczkowski, Jabłońska, 2013) or "(breast) cancer stars" (Kofta 2013). It is not only surviving cancer, but also becoming ill itself that arouses a kind interest in those around one and becomes the main, or even the only reason to nominate someone as cancer heroic (Seale 2002).

Certainly, modern medicine has had a great influence on the processes of removing the taboo of cancer, as it is still developing its arsenal of methods and means used to "save" patients more and more efficiently. However, to do that, it must "fight" stereotypes concerning oncological diseases which are still widespread in society, and convince non-diagnosed people to undergo screening or diagnostic tests. Representatives of medicine and journalists dealing with health issues claim that, at present, cancer is a chronic or even a curable disease in some instances. Their statements are legitimized by patients in their roles of "living evidence" of medical successes, who publically talk about their happy lives with what is known as conditional health. For their part, patients are interested in cooperating with professionals, as they want to "repay their debts" and show gratitude for having their lives saved, warn people about the risk of cancer, offer hope to other patients and their families, and, what is relatively rare in Poland if it ever happens, have direct access to modern medical expertise and influence the directions of research on cancer (Brown, Zavestoski, McCormick, Mayer, Morello-Frosch, Gesior Altman 2004).

Therefore, it may be said that physicians, journalists, and people close to cancer-sufferers, as well as other patients, encourage people with cancer in one way or another to disclose their experiences. That "emancipation" and social activity of patients has become one of the distinguishing features of the present times, called, among other things, the therapy culture (e.g. Furedi 2003) or the remission society (Frank 2005). Narrations concerning the illness, published in electronic and traditional media, have already been recognized as powerful tools of patients' groups, used for educational, social, or even political purposes (referring to influence on decision-makers responsible for regional and nation-wide health policies) (Rabeharisoa, Moreira, Akrich 2014). The cultural recognisability of biocitizens (the expression formed by Nikolas Rose and Carlos Novas 2005) results in a greater social respect demonstrated to patients, attention given to their statements, recognition for their group efforts, and support for their initiatives.

The above context of the discussion concerning social support received (and offered) by people suffering from cancer concerns, most of all, the western world; in Poland, we may observe only selected (and often rather accidentally "transplanted" onto our ground) phenomena of the complex process of social activation of patients who, e.g. in the USA, have already achieved significant and desired changes 
in health services and in their life conditions. Critical analyses of phenomena taking place in highly-developed countries enable us to understand and assess the situation of Polish patients with oncological diseases, in terms of available possibilities of satisfying their health-related, psychological, social, and other needs.

\section{Critical reflection on the birth, development, and... stagnation of the movement of Polish Amazons in the context of carrying out the task of supporting the movement's members and other patients}

When the first club of post-mastectomy women was established in the 1980s in Warsaw, (breast) cancer had the worst connotations for Polish people and evoked overwhelming fear. Low detectability of the cancer in society, bad prognoses for patients after the diagnosis (whose disease was usually diagnosed at an advanced stage), high mortality among the patients, and "unfriendly" medicine as well (which was authoritarian, objectified patients, focused on pathologies, and hid its own deficiencies in the militarised language used for descriptions of therapeutic procedures, in accusations against patients of "growing a cancer in themselves", and in using methods making one think of terrible tortures, which mutilated and incapacitated the people they were used on) etc. did not raise trust and did not contribute to developing the health competences of Polish people. On the contrary, they discouraged possible patients who were anxious about observed symptoms and encouraged people already "afflicted" with cancer to keep their experiences secret, all the more so that it was generally believed that you could become infected with cancer even during an everyday conversation (ref. to Kryńska, Marzec 2016).

The situation of women suffering from breast cancer was very difficult and unpleasant; after amputation, they were deeply mutilated (at that time, large pieces of breast muscle were removed during the surgery according to the approach saying that "you should remove as much as possible"), rendered incapacitated (it was difficult to use the arm on the operated side as all lymph nodes in the armpit were removed or, as a matter of fact, torn out), terrified that they were going to die soon, lonely, and convinced that they had stopped being women (as they were deprived of feminine attributes, i.e. breasts and sometimes also hair for a certain time). Thus, in general, they were left to themselves, in ignorance, isolation, and fear. Women hid their experiences not only from people from their social environment, but even from their closest family, including husbands (for fear that their husbands will abandon them). Participation in a patients' group could be the best solution for them, but it involved "confessing" to cancer. No wonder that, at the beginning, such groups were formed and run by physicians (or nurses appointed by them), who persuaded their patients "in conspiracy" to participate in meetings. The groups run by them pursued only two goals: to provide patients with medical 
information (mainly in the form of lectures delivered by oncologists) and to organize rehabilitation classes, making the hand on the side of the removed breast fitter (in the 1980s, rehabilitation addressed at women after breast cancer had just started to develop) (ref. to Zierkiewicz, Wechmann 2016).

In the late 1980s and early 1990s, groups for post-mastectomy women, supervised by representatives of the world of medicine, functioned in several largest Polish cities. It is easy to imagine that they did not satisfy the needs of the patients, but those of the specialists, who even tried to discourage the participants from becoming close with each other (physicians were also convinced that the death of cancer-sufferers was only a matter of time, and rather a short time at that) and forced them to assume the physicians' way of thinking about the disease and coping after treatment. A very strong position in the initial period of forming patients' groups in regional hospitals was taken by Krystyna Mika (1995), doctor of rehabilitation from the Warsaw Oncology Centre and author of a publication about functioning after cancer treatment, of which there were few at that time.

Following the spirit of those times, Mika believed that medical expertise lies within the domain of specialists and, as a consequence, it should not be available to patients; only selected information should be disseminated among them and then only by physicians or other specialists. In a way, she monopolized the expertise on the psychological and physical functioning of women with breast cancer and that is why members of patients' groups in other cities were referred by physicians to consultation appointments with Mika. She found it difficult to accept the American model of patient activism, which openly involved the autonomy of patients in contacts with physicians, which she was able to observe abroad in 1997, and the goals of which she could discuss with representatives of Reach-To-Recovery in Warsaw several years later. However, it was Krystyna Mika that created a space for patients from various centres to contact each other, although they finally rebelled against her. But for her dedication and determination, it would not have been possible to organize rehabilitation camps where, after physiotherapy classes held by professionals and trainees learning the job, discussions were held on issues which were most important for the patients, i.e. how to maintain an intimate relationship with their husbands, how to hide that a breast is missing, where to purchase a prosthesis, how to deal with fear, how to eat etc.

The groups formed and managed by oncologists set the style of activity and goals for other organizations, which were established by patients themselves. In 1993, following the formation of a federation of 14 already existing clubs, a new stage began in the development of the Polish movement of women after breast cancer treatment. Although a statute was adopted stating that members and presidents of clubs could only be patients with cancer, priorities still included raising medical awareness in people participating in meetings (which may be called information support) and facilitating access to specialist rehabilitation classes 
(instrumental support). In a sense, those first groups, as well as ones formed later, refrained from setting any values for themselves.

In the 1990s, feminist awareness grew in Poland; as a consequence, a recognition slowly dawned of the unequal position of women and men in our conservative society. Paradoxically, after 1989, in the newly formed liberal democracy, Polish people were openly encouraged to contest the "masculinization of women" in the professional area, imposed in the socialist period, and to return to traditional gender relationships, which were deemed natural. However, even if ideological disputes were held in the public sphere about women's place in the society and family, groups of cancer patients were not interested in them. They lived somehow outside that debate, focused on themselves and their own survival. As a matter of fact, many of them were elderly and, even if they were professionally active at one time, their reasons for working were mainly financial. Feminists younger than them by a generation, or even two or three generations, dealt, most of all, with reproductive issues (in particular the right to abortion), which were important for them, and did not seek contact with elderly patients. To paraphrase Ewa Malinowska (2001), it may be said that a division into elderly and diseased traditionalists and young and healthy feminists became visible at that time. They differed very much from each other, but I am going to discuss only one issue here, i.e. their different attitude to femininity. Patients with breast cancer tried to keep it, i.e. tried to play their femininity according to dominating social standards despite mutilating medical interventions. Therefore, their femininity was superficially natural, but it was, in fact, a show or a masquerade, it was queer (Wiatr 2006). Feminists, on the other hand, deconstructed the category of femininity and recognized a culturally formed matrix in it, which was reproduced/manufactured in the process of following an idealized model. The attitudes, beliefs, and goals of the elderly patients and much younger feminists remained separate; there was no reason to start any cooperation.

In that context, what seems to be a paradox is the name used most frequently by the associations of breast cancer survivors to describe themselves (and to selfidentify themselves in a group), i.e. Amazonki (the Amazons). The world "Amazon" was recognized as neutral as well as charming and full of dignity. The idea to use it came from Zofia Michalska, one of the first patients rehabilitated by Krystyna Mika and her dedicated colleagues (Klimowicz 2007). The expressions which were used until recently, i.e. "a post-mastectomy patient" or "a women with a malign tumour/ breast cancer" have either become inappropriate (as more and more patients underwent breast-saving surgery) or sounded like an affront to patients. Women patients with breast cancer became Amazons in the early 1990s; however, they had as much in common with those legendary Amazons from whom their name originated as with the feminists referred to above. I can see the paradox in using that name as they desired to "hide" the possibly stigmatizing information that they suffered from cancer and, at the same time, to emphasize the fact of having no breast/having had a breast removed (the word "Amazons" comes from Greek, 
$a$ - no and mazos - breasts). What should also be underlined here is the fact that at present that name is used, most of all, by activists associated in clubs. Passing over the complexity and not completely justified use of the name of that ancient tribe, the word "Amazons" has already stuck to women involved socially in "fighting cancer" in Poland by supporting other patients in the process of recovery, seeking help from each other in an active manner, and being an example for people doubting the sense of undergoing screening, diagnostic tests, or oncological treatment. It is also important that the name of Amazons ensures group identification, so it participates in the processes of regulatory support described by Katarzyna Popiołek as consisting in providing models of action, social roles, and values as well as an "assessment of people and social phenomena, and guidance for selection of a way of proceeding, maintaining a specific image of an individual which may become a source of recognition and acceptance" (Popiołek 1996: 34).

Throughout the 1990s and until the middle of the last decade, the Amazon movement developed quite intensively. In many cities and towns in Poland, associations were formed which, according to their statutes, were supposed to create favourable conditions for the satisfaction of the needs of women patients, most of all in relation to facilitating physical functioning of patients and organization of rehabilitation (instrumental support); providing necessary knowledge improving the patients' chance for a successful, healthy, and long life (information support); establishing contact with people in a similar health situation; sharing experiences (emotional support); receiving advice, as well as stimuli and encouragement for action (instrumental and appreciative support); and spending free time in an active and creative manner (social support) etc. The meetings worked as a protective buffer which helped participants to satisfy their emotional needs, receive psychological help (from a psychologist or a oncology psychologist specialist employed by the club), and consult an oncologist (invited to the club or cooperating with the club). Apart from that, the clubs operated according to the self-help principle, i.e. all members were volunteers dedicating their time to help themselves and others (including women waiting for surgeries in oncological wards).

The current stage of the development of the Amazon movement in Poland began in 2010. The movement became established and it also became a part of the public imagination. The Amazons could not, perhaps, be seen too often in the public sphere, e.g. on the streets of cities (exceptions include September and October marches and annual pilgrimages to Jasna Góra on the first Saturday in October; ref. to Samson, Jansen, Notermans 2014), but the topic of breast cancer was still present in both traditional and electronic media, partly because of the popular commercial symbol of the pink ribbon. In 2010, the Amazon movement initiated a debate on the future of cancer patients and Polish health policy, managed to motivate various social organizations, and led the formation of the Polish Coalition of Oncological Patients; later, it put the strongest pressure on politicians in the government in relation to the so-called oncological package (Zierkiewicz, Wech- 
mann 2016: 157-165). On the other hand, however, stagnation in clubs and the movement itself could have been observed for a long time. The clubs were dominated by older women (over 60) who meet to spend an hour or two in each other's company in a pleasant atmosphere. Younger women, whose numbers in the population of patients have increased, are either not able to reach a club during its opening hours (they work professionally, take care of their families, raise small children) or are disappointed with "the pensioners' climate", absence of their peers in the group, unwillingness of other women to take up new social activities, the established hierarchy of positions in the group structure etc.; they join online initiatives or form their own organizations composed of several members (ref. to Mazurkiewicz 2012; Zierkiewicz, Wechmann 2016).

However, as the Amazons clubs gather thousands of activists (between 11,000 and 25,000 women, as estimates show; ref. to Mazurkiewicz 2012: 124 and 126), it may be assumed that they are a place where patients receive valuable assistance. Below, I will discuss conclusions from selected research on social support offered to women with breast cancer in self-help groups.

\section{Importance of support provided in self-help groups for women with breast cancer}

No detailed research on the functioning of the Amazon clubs has been conducted in Poland so far. Certain issues were discussed, albeit very superficially, by Małgorzata Gajda $(2007,2010)$ and Małgorzata Adamczak $(1997 ; 2000)$ among others. Most of all, groups of women helped by filling in questionnaires concerning specified research issues. Information was gathered from club members on e.g. the professional functioning of women after breast cancer treatment (Mazurkiewicz 2012) or recognition of available social support by patients (Sępowicz-Buczko 2010). Therefore, no one has managed to describe completely of what the phenomenon of supporting social activity consists; as a result, one may find out much more about the experience of involvement in club operations, the formation of an Amazon's identity and/or coping better owing to the establishment of relationships with other patients by reading autobiographies written by patients, e.g. Joanna Grzelka-Kopeć (2009), Lucyna Korycka (2011), Krystyna Wechmann (Zierkiewicz, Wechmann 2013), or Kazimiera Lissy-Kalafarska (2014).

Research by western scientists clearly shows that support received from family and friends differs from that provided to patients by other women with breast cancer (cf. e.g. Ussher, Kirsten, Butow, Sandoval 2006). Close relationships, care, raising one's spirits etc. are not sufficient in coping with "situations which may not be avoided" (ref. to Sędek 1991). Relations and friends do not always want or are unable to support patients; moreover, in the process of providing assistance, they often experience many burdens and difficulties themselves, ones that make them 
burnt out and discouraged (ref. to e.g. Ell 1996). Furthermore, they do not understand the patient's experiences as they are healthy and often force the patient to assume the modern role of "a courageous hero" or the traditional role of "a cancer victim" (Atkins 2016).

The discussion of benefits derived from the participation in the operation of patient organizations should start from a comment on the context in which such groups operate, i.e. the social perception of cancer. In the environment with a negative attitude towards oncological diseases which stigmatizes that affliction, patients are also stigmatized and, as a consequence, they feel isolated. The social conspiracy of silence, no discussion of the disease in the media, low levels of curability due to low advancement of medical expertise and technology etc. fuel fear of cancer and favour the belief in various myths (Daher 2012). Such beliefs and attitudes are still very frequent in many societies, e.g. in Arabic (cf. Dardas, Ahmad 2015) or Indian communities (cf. Pankaj, Nazneen, Kumari, Kumari, Choudhary, Kumari, Kumari 2018). It would seem that stereotypical beliefs about cancer are a thing of the past in Poland; however, news published by the media suggesting the growing popularity of unconventional medicine or the demands of the "antivaccination" movement raise doubts as to that. However, attitudes of patients with breast cancer have clearly changed (cf. Salamon 2010), which has also been caused by the mass media cooperating with physicians and following the mission of raising social awareness concerning oncological diseases under the aegis of the pink ribbon. The open discussion on breast cancer using the "language of science", which contains no emotions, has enabled a change in the cultural repertoire of beliefs concerning that disease. That does not mean that patients do not feel irrational fear or do not think about their chances of survival fatalistically (Toader 2018); however, they may cope with "black thoughts" e.g. by consulting physicians or modelling their behaviour based on role models presented by volunteers-Amazons met in hospital.

A significant change with reference to cancer in the public sphere in Poland may, however, be demonstrated by quite a number of stories told by famous people (e.g. Stuhr 2012), people from the media (e.g. Gucewicz 2015), and people who were previously unknown (e.g. Michalczyk 2014). Having observed activists of other social movements (e.g. alcoholics anonymous), it may be stated that public disclosure plays a crucial role in the context of removing social taboos around a specific problem, and in the personal process of the recovery of the afflicted person (ref. to e.g. Osiatyński 2003, 2012). The "role of a patient" is based on a "rule" of passivity and obedience as well as on silence. A confession, which usually means speaking on a personally and/or socially important issue, makes patients become active and, as a consequence, voice their disobedience towards the expectations of them. Silent patients are isolated cases in the hospital space; when they start to talk to each other, they take up a certain social action which may bring 
a relationship and an understanding as to a change of the existing order. At first, physicians were afraid of active, "talkative", and, what follows, difficult patients; they preferred to keep patients ignorant so that patients were silent in contact with them, and talked about the diagnostic results and the course of treatment only with patients' relatives. It turned out relatively quickly that well-informed and enquiring patients are more involved in their treatment, more willing to cooperate with physicians, and more satisfied with the help they receive (Gordon, Paci 1997). When representatives of the medical profession became aware of that, they changed their attitude to the Amazons.

Most of all, however, public disclosures had very positive effects for the patients themselves, as they were treated by those around them as a demonstration of courage and adaptation and, at the same time, provided the possibility of establishing relationships with other patients, obtaining information, sharing experiences and finding inspiration, hope, encouragement etc. What is more, as I have already mentioned, at present the belief is becoming very popular that refraining from a confession about suffering from (breast) cancer is a mistake and may have negative consequences, e.g. an unnecessary mental burden or a feeling of isolation (cf. e.g. Tsuchiya, Horn, Ingham 2015; Figueiredo, Fries, Ingram 2004). Obviously, not all patients feel the need to make a public disclosure by giving an interview in the mass media or starting an online diary (blog); however, at present, they do not feel any longer that they are discouraged from sharing their problems with people surrounding them, i.e. with their family, friends, or colleagues. It seems that, for many people, a patients' association is a place where it is easiest to summon up the courage to talk about one's problems. The reason is the fact that such an association is a place where one may prepare, in a way, to pass through all the stages of the disclosure (por. Korsbek 2013) and where patients learn how to talk about their new life situation (here: e.g. stop using metaphors of "a fight" preferred by medicine, but inadequate for patients, Broom, Kenny, Kirby 2018). Then, unnoticeably, a process of transformative learning is initiated, in particular with reference to the understanding of the experienced crisis, general coping, and recognizing the role and place of the illness in life (Hoggan 2014). It is also more and more often said that patients' organizations help in coping with "the art of waiting", i.e. life in uncertainty, which is difficult to bear on one's own, as being in a group facilitates acceptance of survivorship which is still uncertain (Broom, Kenny, Kirby 2018).

In a group of various women who, nonetheless, have a similar and identityforming experience, patients can also "analyse" and "verify" the dominant cultural meanings of cancer, i.e. medical and media-related ones. The first of them are questioned e.g. by criticising the (self)objectification forced on patients during hospital treatment or by talking about the holistic nature of the experienced suffering (cf. Best, Aldridge, Butow, Olver, Webster 2015). The latter ones, i.e. images of cancer in the media, may be questioned in group discussions as inadequate presentations of the disease (here: presentations sexualising the disease) or ones forcing 
optimistic attitudes and positive thinking on patients (Ehrenreich 2007, cf. also McCreaddie, Payne, Froggatt 2010). Apart from criticising, patients' organizations create favourable conditions for conferring meanings on cancer collectively, ones which may be disseminated in the public space, e.g. on social media or through social campaigns. In that manner, breast cancer survivors may take part in creating a new attitude to the disease and to themselves: their organizations often take the role of an advocate by becoming involved in "the social production of what cancer is and how life with cancer may/should look" (Gibson, Broom, Kirby, Wyld, Lwin 2015: 985; cf. also Zierkiewicz, Wechmann 2016).

At the beginning of their involvement in the meetings of a self-help group, women do not always become aware of the great number of ways in which such a group is important for their physical and mental state and the quality of further life. That does not mean a better mood or a feeling that they are not lonely in their "nightmare", but a change occurring in their attitude to the world and to themselves (Atkins 2016). As a matter of fact, even scientists focusing in their research on the issue of the participation of patients in social organizations do not always recognize the complexity of that issue. Many works still describe research results in reference to the classical view of social support, by listing types of support provided to patients in the group (e.g. Toledo, Ochoa, Farias 2019; Campell Phaneuf, Deane 2004), by comparing support provided traditionally with assistance available on-line (e.g. Houlihan, Tariman 2017), or by focusing on the fitness-related and relationship-forming aspect of physical activity (Ireland, Finnegan-John, Hubbard, Scanlon, Kyle 2018 among others) etc.

Regardless of whether the issue of participation in a patients' movement is presented narrowly (here: limited to an analysis of structure and type of help relationships) or widely (i.e. examined as a social power and cultural phenomenon), similar conclusions are usually drawn concerning the many benefits derived by the ill women involved. Research has often shown that becoming a breast cancer activist increases self-esteem, improves mental and physical state, helps with coping, improves social relationships (e.g. in a family), expands the circle of friends, and makes patients experience a post-traumatic growth and become more physically fit (if they take part in rehabilitation classes) etc. Lately, that list has also been expanded with self-efficacy as a key psychological resource in adapting well to life with cancer (Borjalilu, Kaviani, Helmi, Karbakhsh, Mazaheri 2017).

\section{Final remarks}

The above reflections on the Polish movement of Amazons seem to lead to the conclusion that it has just entered its final period and will, perhaps, vanish completely from the social and political scene soon. In the clubs, there is no exchange of generations; most members are older women (ref. to Zierkiewicz, Wechmann 2013). Younger women with cancer are more willing to visit websites where they 
meet their peers, who understand their needs better and provide them with more efficient support (van Eenbergen, van de Poll-Franse, Heine, Mols 2017; Bender, Katz, Ferris, Jadad 2013).

It may be said with great probability that the Amazon movement will not vanish from the Polish social map, although it is going through a certain stagnation at present. However, individual patients' associations gathered in the movement are persistently following their statutory goals, i.e. they provide efficient support to women during the (conditional) recovery and give them space to "help themselves by helping others". Club members also have much greater possibilities, as they may become involved in influencing state health policy by e.g. patient advocacy or controlling the manner in which the oncological package is realized, one which was introduced with a contribution from their movement.

The Polish Amazons should also start a regular and close cooperation with activists abroad, both from western and eastern countries. The first of them may tell Polish Amazons how a modern health service operates and how professionals take care of their patients' good physical and mental state (cf. Zøylner, Lomborg, Christiansen, Kirkegaard 2019). The latter ones may e.g. use the Amazons' assistance in bringing a change in the attitude of their societies to patients with breast cancer and, what follows, an improvement in their lives.

\section{References}

Adamczak M. (1997) Idea i realizacja wzajemnej pomocy przez stowarzyszenia kobiet po mastektomii, "Psychoonkologia", 1: 95-98.

Adamczak M. (2000) Rola stowarzyszeń samopomocy pacjentów z chorobq nowotworowq in: Psychoonkologia, K. de Walden-Gałuszko (ed.), Kraków: Biblioteka Psychiatrii Polskiej: 117-122.

Atkins L. (2016) Half the battle. Social support among women with cancer, "Qualitative Inquiry", 22 (4): 253-262.

Bender J. L., Katz J., Ferris L.E., Jadad A. (2013) What is the role of online support from the perspective of facilitators of face-to-face support group? A multi-method study of the use of breast cancer online communities, "Patient Education and Counseling", 93 (3): 472-479.

Best M., Aldridge L., Butow P., Olver I., Webster F. (2015) Conceptual analysis of suffering in cancer. A systematic review, "Psycho-Oncology", 24 (9): 977-986.

Borjalilu S., Kaviani A., Helmi S., Karbakhsh M., Mazaheri M.A. (2017) Exploring the role of self-efficacy for coping with breast cancer. A systemic review, "Archives of Breast Cancer", 4 (2): 42-57. 
Broom A., Kenny K., Kirby E. (2018) On waiting, haunting and surviving. Chronicling life with cancer through solicited diaries, "The Sociological Review", 66 (3): 682-699.

Brown P., Zavestoski S., McCormick S., Mayer B., Morello-Frosch R., Gesior Altman R. (2004) Embodied health movements. New approaches to social movements in health, "Sociology of Health and Illness", 26 (1): 50-80.

Campell H. S., Phaneuf M. R., Deane K. (2004) Cancer peer support programs - do they work?, "Patient Education and Counseling", 55 (1): 3-15.

Daher M. (2012) Cultural beliefs and values in cancer patients, "Annals of Oncology", 23 (3): 66-69.

Dardas L. A., Ahmad M. M. (2015) Myths and misconceptions about cancer. Findings from Jordan, "Medical Journal", 2 (6): 88-93.

Easley J. (2019) Motivations for cancer history disclosure among young adult cancer survivors, "Journal of Cancer Survivorship", 13 (3): 447-458.

van Eenbergen M. C, van de Poll-Franse L. V, Heine P., Mols F. (2017) The impact of participation in online cancer communities on patient reported outcomes: systematic review, “JMIR Cancer", 3 (2): e15. DOI: 10.2196/cancer.7312

Ehrenreich B. (2007) Pathologies of hope, "Harper's Monthly", 1: 9-11.

Ell K. (1996) Social networks, social support and coping with serious illness. The family connection, "Social Science \& Medicine", 42 (2): 173-183.

Figueiredo M. I., Fries E., Ingram K. M. (2004) The role of disclosure patterns and unsupportive social interactions in the well-being of breast cancer patients, "PsychoOncology", 13 (2): 96-105.

Frank A. (2005) The remission society in: The Sociology of Health and Illness, P. Conrad (ed.), New York: Worth Publishers: 163-166.

Furedi F. (2003) Therapy culture. Cultivating vulnerability in an uncertain age, London, Routledge.

Gajda M. (2007) O przyjaźni na zawsze - Amazonki o relacjach nawiazywanych w Klubie Kobiet po Mastektomii in: Kobieta i (b)rak. Wizerunki raka piersi w kulturze, E. Zierkiewicz, A. Łysak (ed.), Wrocław: MarMar: 35-41.

Gajda M. (2010) Kluby Amazonek jako grupy wsparcia społecznego in: Starość u progu XXI wieku. Uniwersytety Trzeciego Wieku wobec problemów starzejącego się społeczeństwa, A. Kobylarek, E. Kozak (ed.), Wrocław: Agencja Wydawnicza AGRI: 82-87. 
Gibson A., Broom A., Kirby E., Wyld D., Lwin Z. (2017) The social Deception of women with cancer, "Qualitative Health Research", 27 (7): 983-993.

Gordon D., Paci E. (1997) Disclosure practices and cultural narratives. Understanding concealment and silence around cancer in Tuscany, Italy, "Social Science \& Medicine", 44 (10): 1433-1452.

Gucewicz K. (2015) Jeszcze wczoraj miałam raka, Warszawa, Melanż.

Grzelka-Kopeć J. (2009) Pokonać smoka, Kraków, Drukarnia “Mellow”.

Hitchens Ch. (2013) Śmiertelność, transl. by Radosław Madejski, Katowice, Sonia Draga.

Hoggan Ch. (2014) Insights from breast cancer survivors. The interplay between context, epistemology, and change, "Adult Education Quarterly", 64 (3): 191-205.

Houlihan M. C., Tariman J. D. (2017) Comparison of outcome measure for traditional and online support groups for breast cancer patients. An integrative literature review, "Journal of the Advanced Practitioner in Oncology", 8 (4): 348-359.

Ireland A. V., Finnegan-John J., Hubbard G., Scanlon K., Kyle R. G. (2019) Walking groups for women with breast cancer. Mobilising therapeutic assemblages of walk, talk and place, "Social Science \& Medicine", 231: 38-46.

Kaczkowski J., Jabłońska K. (2013) Szału nie ma, jest rak, Warszawa, Więź.

Klimowicz M. (2007) Starożytne Amazonki symbolem dla kobiet po mastektomii? in: Kobieta i (b)rak. Wizerunki raka piersi w kulturze, E. Zierkiewicz, A. Łysak (eds.), Wrocław, MarMar: 9-13.

Kofta K. (2013) Lewa, wspomnienie prawej. Dziesięć lat później, Warszawa, Świat Książki.

Korsbek L. (2013) Disclosure. What is the point and for whom?, "Journal of Mental Health", 22 (3): 283-290.

Korycka L. (2011) Zapisane w gwiazdach czy genach?, Żyrardów, Centrum Kultury w Żyrardowie.

Kryńska J., Marzec T. (2016) Onkolodzy: Walka na śmierć i życie, Warszawa, The Facto.

Lissy-Kalafarska K. (2014) Dziennik Amazonki. Od Rewala do Rewala, Kalisz, Edytor.

Malinowska E. (2001) Kobiety i feministki, "Kultura i Społeczeństwo", 2: 21-38. 
Mazurkiewicz A. (2012) Mam go! Rak piersi - strefa prywatna, strefa publiczna, Warszawa, Amazonki Warszawa-Centrum.

McCreaddie M., Payne S., Froggatt K. (2010), Ensnared by positivity. A constructivist perspective on 'being positive' in cancer care, "European Journal of Oncology Nursing", 14 (4): 283-290.

Michalczyk M. (2014) Zabiłam raka śmiechem, Poznań, Contrabanda.

Mika K. (1995) Po odjęciu piersi, Warszawa, Wydawnictwo Lekarskie PZWL.

Munro H., Scott S. E., King A., Grunfeld E. A. (2015) Patterns and predictors of disclosure of a diagnosis of cancer, "Psycho-Oncology", 24 (5): 508-514.

Osiatyński W. (2003) Rehab, Warszawa, Iskry.

Osiatyński W. (2012) Litacja, Warszawa, Iskry.

Pankaj S., Nazneen S., Kumari A., Kumari S., Choudhary V., Kumari J., Kumari A. (2018) Myths and taboos. A major hindrance to cancer control. "Inherited knowledge" a blessing curse. Surgery after 21 cycles of chemotherapy "A surgeon's ordeal", "Indian Journal of Gynecologic Oncology", 16 (2), https://doi.org/10.1007/s40944-017-0172-7

Popiołek K. (1996) Wsparcie społeczne - zarys problematyki in: Psychologia pomocy. Wybrane zagadnienia, K. Popiołek (ed.), Katowice, Wydawnictwo Uniwersytetu Śląskiego: $30-45$.

Rabeharisoa V., Moreira T., Akrich M. (2014) Evidence-based activism. Patients', users' and activists' groups in knowledge society, "BioSocieties", 9 (2): 111-128.

Rose N., Novas, C. (2005) Biological citizenship in: Global assemblages. Technology, politics and ethics as anthropological problems, A. Ong, \& S. Collier (ed.), Malden, Blackwell Publishing: 439-463.

Salamon M. (2010) Przewodniczq̨ca klubu kobiet „odradzających się z popiołów” in: E. Zierkiewicz, Rozmowy o raku piersi. Trzy poziomy konstruowania znaczeń choroby, Wrocław, Atut: 158-173.

Samson J., Jansen W., Notermans C. (2015) Restoring femininity through religious symbols after breast cancer. The case of the Polish Amazonki, "Journal of Gender Studies", 24 (6): 660-676.

Seale C. F. (2002) Cancer heroics: a study of news reports with particular reference to gender, "Sociology", 36 (1): 107-126.

Sędek G. (1991) Jak ludzie radzq sobie z sytuacjami, na które nie ma rady? in: Złudzenia, które pozwalają żyć, M. Kofta, T. Szustrowa (eds.), Warszawa, Państwowe Wydawnictwo Naukowe: 289-319. 
Sępowicz-Buczko K. (2010) Poczucie sensu życia a wsparcie społeczne „Amazonek”, Legnica, Wydawnictwo PWSZ.

Sontag S. (1999) Choroba jako metafora. AIDS i jego metafory, transl. by Jarosław Anders, Warszawa, Państwowy Instytut Wydawniczy.

Stuhr J. (2012) Tak sobie myślę. Dziennik czasów choroby, Kraków, Wydawnictwo Literackie.

Toader E. (2018) How culture influences the perception of serious diseases, "Revista de Cercetare si Interventie Sociala", 63: 220-229.

Toledo G., Ochoa C. Y., Farias A. J. (2019) Exploring the role of social support and adjuvant endocrine therapy use among breast cancer survivors, "Supportive Care in Cancer", doi.org/10.1007/s00520-019-04814-0

Tsuchiya M., Horn S., Ingham R. (2015) Social disclosure about lymphoedema symptoms. A qualitative study among Japanese breast cancer survivors, Psychology, "Health \& Medicine", 20 (6): 680-684.

Ussher J., Kirsten L., Butow P., Sandoval M. (2006) What do cancer support groups provide which other supportive relationships do not? The experience of peer support group for people with cancer, "Social Science \& Medicine", 62 (10): 2565-2576.

Wiatr A. (2006) Spisane z ciała. Tożsamość kobiet, które doświadczyły mastektomii in: Queerowanie feminizmu. Estetyka, polityka czy coś więcej?, J. Zakrzewska (ed.), Poznań, Konsola: 133-152.

Zierkiewicz E., Wechmann K. (2013) Amazonki - moje życie. Historia ruchu kobiet po leczeniu raka piersi z biografiq liderki w tle, Inowrocław, Fundacja Ekspert-Kujawy.

Zierkiewicz E., Wechmann K. (2016) Życie od nowa. Społeczne zaangażowanie Amazonek - aktywnych pacjentek, Poznań, Federacja Stowarzyszeń "Amazonki”.

Zøylner I. A., Lomborg K., Christiansen P. M., Kirkegaard P. (2019) Surgical breast cancer patient pathway: Experiences of patients and relatives and their unmet needs, "Health Expectations", 22 (2): 262-272. 